\title{
Host range studies of Fusarium oxysporum, causal agent of seedling wilt disease of Acacia mangium
}

\author{
SOLEHA SOLEHA ${ }^{1}$, AHMAD MUSLIM $^{2, \bullet}$, SUWANDI SUWANDI $^{2}$, SABARUDDIN KADIR $^{3}$, \\ RAHMAT PRATAMA ${ }^{1}$ \\ ${ }^{1}$ Program of Agriculture Sciences, Faculty of Agriculture, Universitas Sriwijaya. Jl Raya Palembang-Prabumulih Km 32, Indralaya, Ogan Ilir 30662, \\ South Sumatra, Indonesia \\ ${ }^{2}$ Department of Plant Protection, Faculty of Agriculture, Universitas Sriwijaya. J1 Raya Palembang-Prabumulih Km 32, Indralaya, Ogan Ilir 30662, South \\ Sumatra, Indonesia. Tel./fax.: +62-896-3874-9695, `email: a_muslim@unsri.ac.id \\ ${ }^{3}$ Department of Soil Sciences, Faculty of Agriculture, Universitas Sriwijaya. Jl Raya Palembang-Prabumulih Km 32, Indralaya, Ogan Ilir 30662, South \\ Sumatra, Indonesia
}

Manuscript received: 15 September 2021. Revision accepted: 7 December 2021.

\begin{abstract}
Soleha S, Muslim A, Suwandi S, Kadir S, Pratama R. 2021. Host range studies of Fusarium oxysporum, causal agent of seedling wilt disease of Acacia mangium. Biodiversitas 23: 25-32. Fusarium oxysporum is a serious pathogen that causes severe wilt disease in commercial nurseries of Acacia mangium in South Sumatra, Indonesia. This study aimed to investigate the host range of $F$. oxysporum as a nursery wilt pathogen in A. mangium and several forests and industrial plants. Three isolates of $F$. oxysporum with different translation elongation factor $($ tef $1-\alpha)$ sequences were tested for pathogenicity on different Fabaceae family plants and the growth of population was also observed. The results showed that all three isolates were able to infect all the tested plants with different reactions to wilt disease. Acacia crassicarpa and Falcataria moluccana were highly susceptible; Archidendron pauciflorum, Leucaena leucocephala, and Parkia speciosa were moderately vulnerable and Acacia auriculiformis was moderately resistant. The pathogen population in A. crassicarpa and $F$. moluccana grew rapidly along with the increase in disease scores, while in $L$. leucocephala it was moderate, and slow in A. pauciflorum, P. speciosa and A. auriculiformis plants. In conclusion, F. oxysporum pathogen, which was isolated from A. mangium, has a wide range of hosts in the Fabaceae family.
\end{abstract}

Keywords: Acacia mangium, Fabaceae, Fusarium oxysporum, host range, seedling wilt

\section{INTRODUCTION}

Acacia mangium (Willd.) is a species of plant that originated in several regions of Indonesia, Papua New Guinea, and Australia, and which, has also been found for a few decades in the humid tropical lowlands of Asia, South America, and Africa (Koutika and Richardson 2019). It is planted on a large scale for industrial purposes and forest restoration in the tropics (Matsumura and Naoto 2011). Since this plant species is known for its fast growth and high adaptability to various environmental conditions (Asif et al. 2017), it is widely used for agroforestry, forestry, and restoration of degraded land (Koutika and Richardson 2019).

Fusarium oxysporum is an important pathogenic fungus that causes wilt disease in different plants all over the world. Soleha et al. (2021) reported that it was identified as the causative agent of vascular wilt in several commercial nurseries of A. mangium in South Sumatra. The main source of transmission is through infected seedlings and soil, which is relatively difficult to treat after contamination. The fungus survives by forming chlamydospores that allow it to live for a long time, even without a host plant (Ignjatov et al. 2012; Koyyappurath et al. 2016; Rana et al. 2017; Muslim et al. 2019). Furthermore, it attacks almost every type of plant, from cultivated to forest and wild (e.g. weeds) (Joshi 2018). This fungus is also able to attack various plant habits such as trees (Zhang et al. 2013), herbaceous plants (Jacobs and Heerden 2012), and vines (Rooney-Latham and Blomquist 2011). Several types of forest plants that have reportedly been attacked by $F$. oxysporum are Pinus massoniana (Luo and $\mathrm{Yu}$ 2020), Tectona grandis (Borges et al. 2018), Pseudotsuga menziesii (Stewart et al. 2011), Acacia mangium (Widyastuti et al. 2013), and others.

Since $F$. oxysporum has a high level of host specificity, it is classified as a formae species (Burkhardt et al. 2019; Taylor et al. 2019). According to Leslie and Summerell (2006) more than 100 formae species and races have been identified and are widespread in the world.

Besides A. mangium, which is the main plant of industrial forestry in Indonesia, other plants, such as Acacia crassicarpa, Acacia auriculiformis, Parkia speciosa, Archidendron pauciflorum, Falcataria moluccana, and Leucaena leucocephala are also important and have high economic value. Considering that they belong to the same family (Fabaceae), they can become the main or alternative hosts for $F$. oxysporum, causative agent of wilt disease. This study aimed to investigate the host range of $F$. oxysporum as a nursery wilt pathogen in A. mangium and several industrial and local forest plants in Indonesia. 


\section{MATERIALS AND METHODS}

\section{Fungal isolates}

Three pathogenic isolates of $F$. oxysporum (AF01, BF05, and DF11) were selected, which were differentiated according to their tef 1- $\alpha$ sequence (Figure 1). Isolates were cultured on PDB liquid medium (potato dextrose broth) and incubated at $26-28^{\circ} \mathrm{C}$ on a shaker $(150 \mathrm{rpm})$ for about five days. Then the mycelia suspension was filtered using two layers of sterile gauze to separate the conidia and hyphae. The conidial concentration was determined using a hemocytometer and then adjusted to a concentration of $10^{6}$ $\mathrm{ml}^{-1}$ for pathogenicity test.

\section{Plant material}

The plants used were members of the Fabaceae family, namely A. crassicarpa, A. auriculiformis, F. moluccana, A. pauciflorum, $P$. speciosa, and $L$. leucocephala, which were one month old. The seedlings were obtained from the Forest Crops Research Institute, South Sumatra. Seedlings were transferred in a mixed medium with cocopeat $(1: 1)$ using a plastic pot of $10 \mathrm{~cm}$ diameter and $10 \mathrm{~cm}$ height, and then placed in a shade house.

\section{Pathogenicity test}

A pathogenicity test was carried out using root dip method, in which the roots were washed under running water and then immersed in $250 \mathrm{ml}$ of conidia suspension $\left(10^{6}\right.$ conidia $\left.\mathrm{ml}^{-1}\right)$ for 15 minutes. The control plants were immersed in sterile distilled water, and the seedlings were transplanted into plastic pots and placed under a house shade. Each isolate was inoculated on 25 plants with five replicates (five plants per-replicate). Then, disease severity was calculated using the method of Muslim et al. (2003a) and the disease index (DI) was classified into following grades, where $0:$ no disease/healthy seedling, $1:$ yellow leaves, 2 : yellow leaves and slightly wilted, 3 : severe wilt, and 4 : dead seedling (Bertetti et al. 2018). Furthermore, plant responses were grouped as, $\mathrm{R}$ : resistant $(\mathrm{DI}=0), \mathrm{MR}$ : moderately resistant/tolerance $(\mathrm{DI}=<1)$, MS : moderately susceptible (DI $=1.0-2.0), \mathrm{S}$ : susceptible $(\mathrm{DI}=2.1-3.0$ ) and HS : highly susceptible (DI $=3.1-4.0$ ). The development of disease was observed 1-21 days after inoculation.

\section{Fusarium oxysporum population}

The population of $F$. oxysporum in the roots was calculated at the end of the experiment using the method of (Muslim et al. 2003b; Li et al. 2009; Horinouchi et al. 2011) with modifications to the surface sterilization of samples. Then the plants were grouped according to severity (disease score) and washed separately under running water to remove soil residues. After that, all plants in each score were surface sterilized using $1 \%$ sodium hypochlorite for 15 minutes, then rinsed three times with distilled water. The samples and water $(1: 100 \mathrm{w} / \mathrm{v})$ were homogenized using blender at $8000 \mathrm{rpm}$ for 10 minutes. Then they were filtered using two layers of sterile gauze and diluted 10 to 1000 times. The suspension was spread on Peptone PCNB agar Media (PPA/Nash Snyder Medium) (Leslie and Summerell 2006) in triplicate (five Petri dishes per replication) and incubated in dark for seven days at room temperature. The number of colony-forming units (CFU) of $F$. oxysporum was calculated on the basis of fresh weight per gram of sample and grouped according to the level of diseases severity.

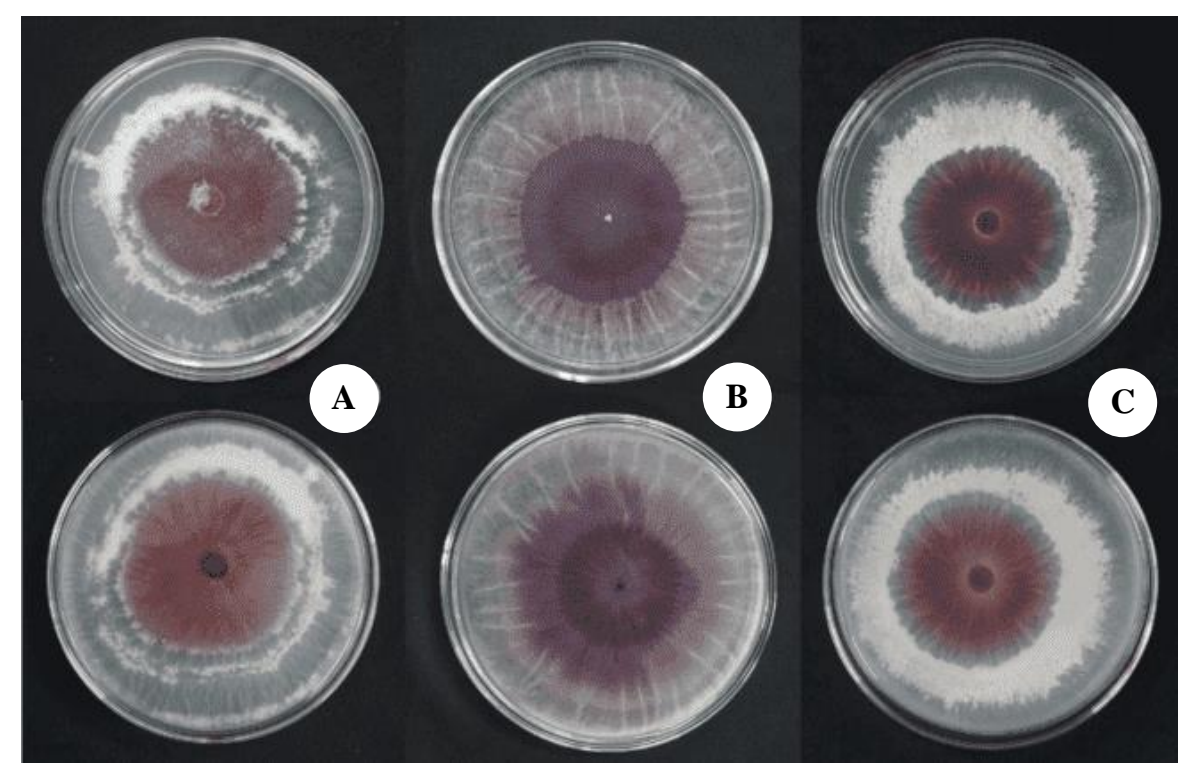

Figure 1. Fusarium oxysporum isolates on PDA medium. A. AF01, B. BF05, and C. DF11. First line: front view; second line: reverse view 

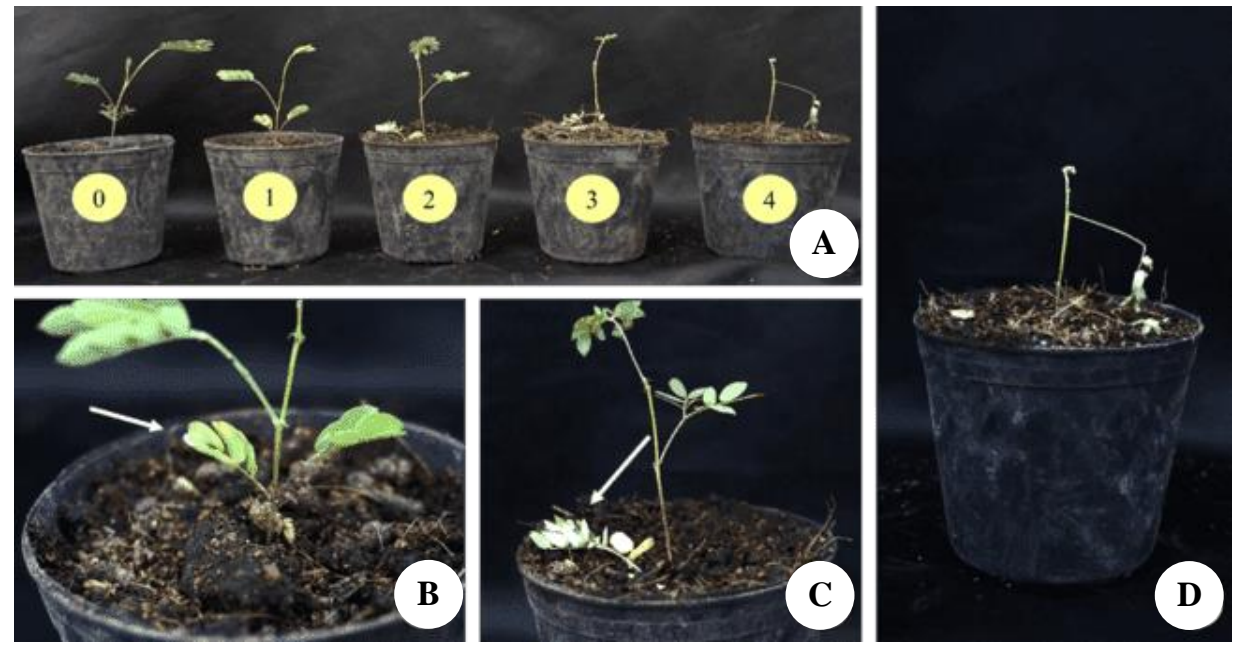

Figure 2. Disease index of Acacia crassicarpa, A. From left: healthy plant to $100 \%$ wilted leaves (score 0-4); B. Initial symptoms: yellowing from oldest leaves; C. Advanced symptoms: falling leaves; D. Dead plant
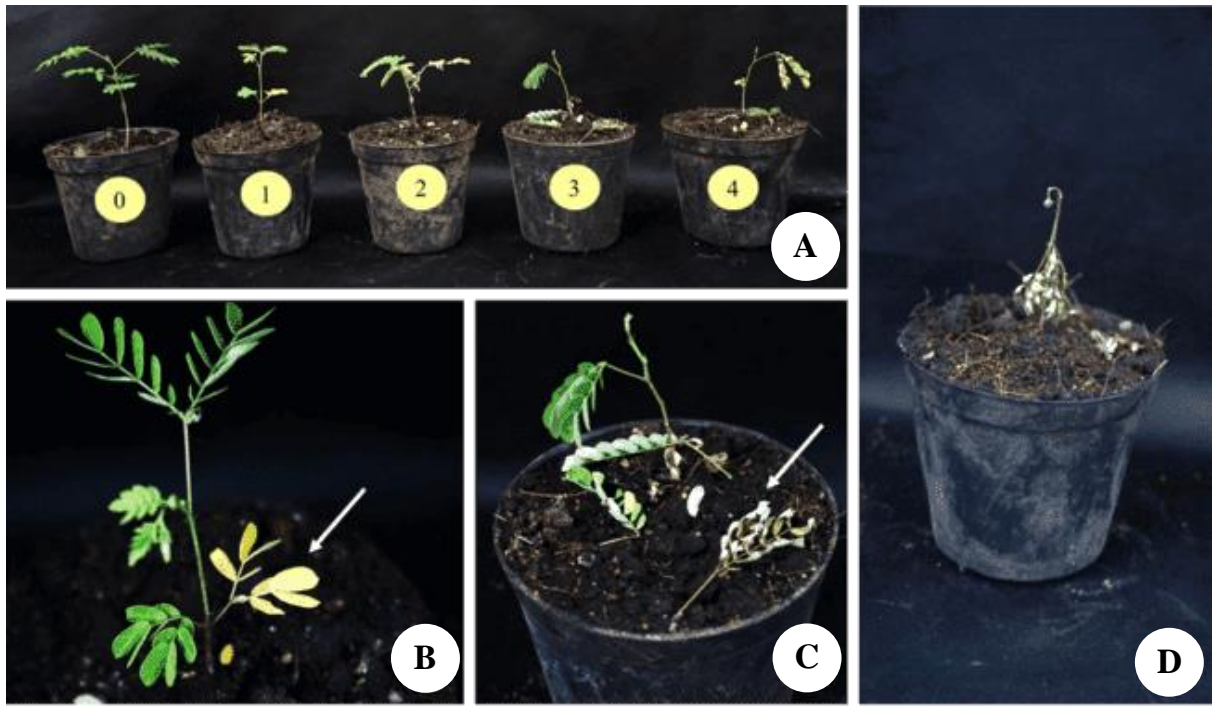

Figure 3. Disease index on Falcataria moluccana, A. From left: healthy plant to $100 \%$ wilted leaves (score 0-4); B. Initial symptoms: yellowing from oldest leaves; C. Advanced symptoms: curved, dry, and falling leaves; D. Dead plant
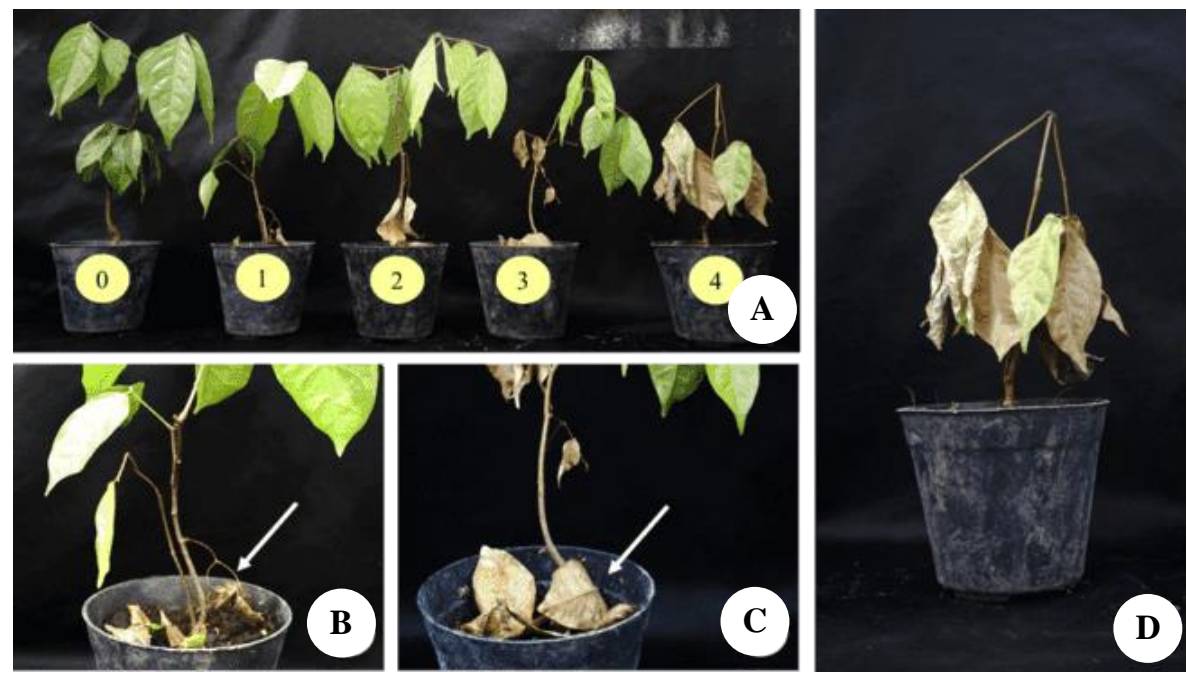

Figure 4. Disease index on Archidendron pauciflorum, A. From left: healthy plant to $100 \%$ wilted leaves (score 0-4); B. Initial symptoms: yellowing and dry from oldest leaves; C. Advanced symptoms: falling leaves; D. Dead plant 

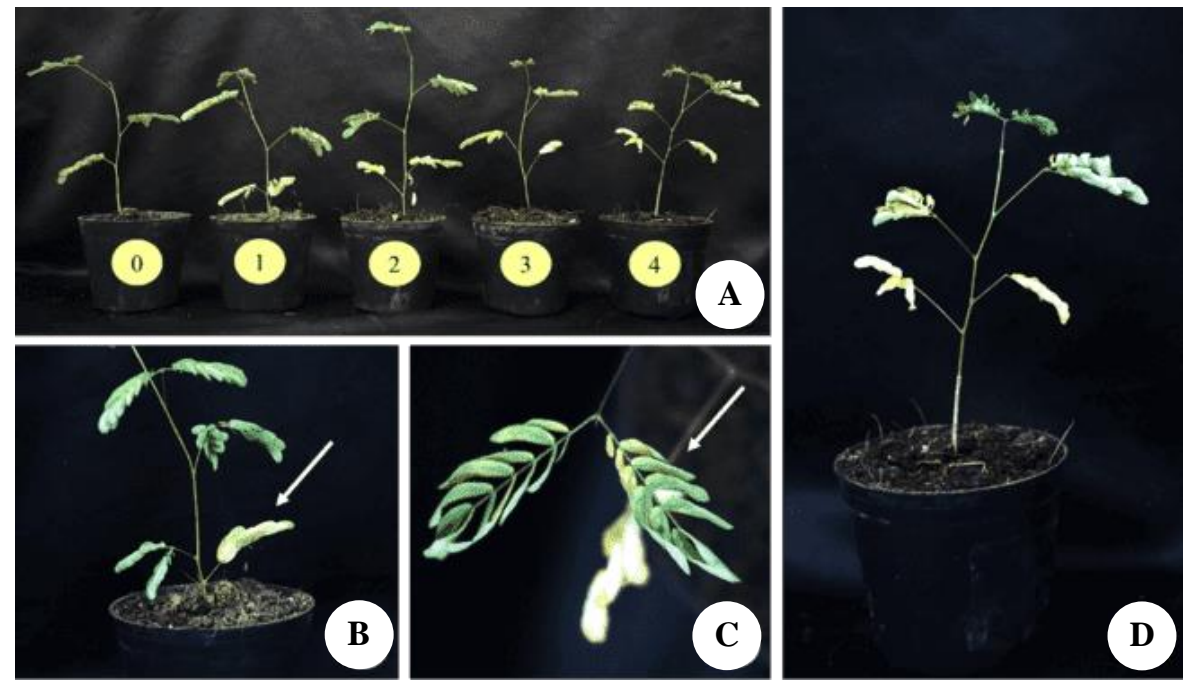

Figure 5. Disease index on Leucaena leucocephala, A. From left: healthy plant to $100 \%$ wilted leaves (score 0-4); B. Initial symptoms: yellowing from oldest leaves; C. Advanced symptoms: curved leaves; D. Yellowing upward
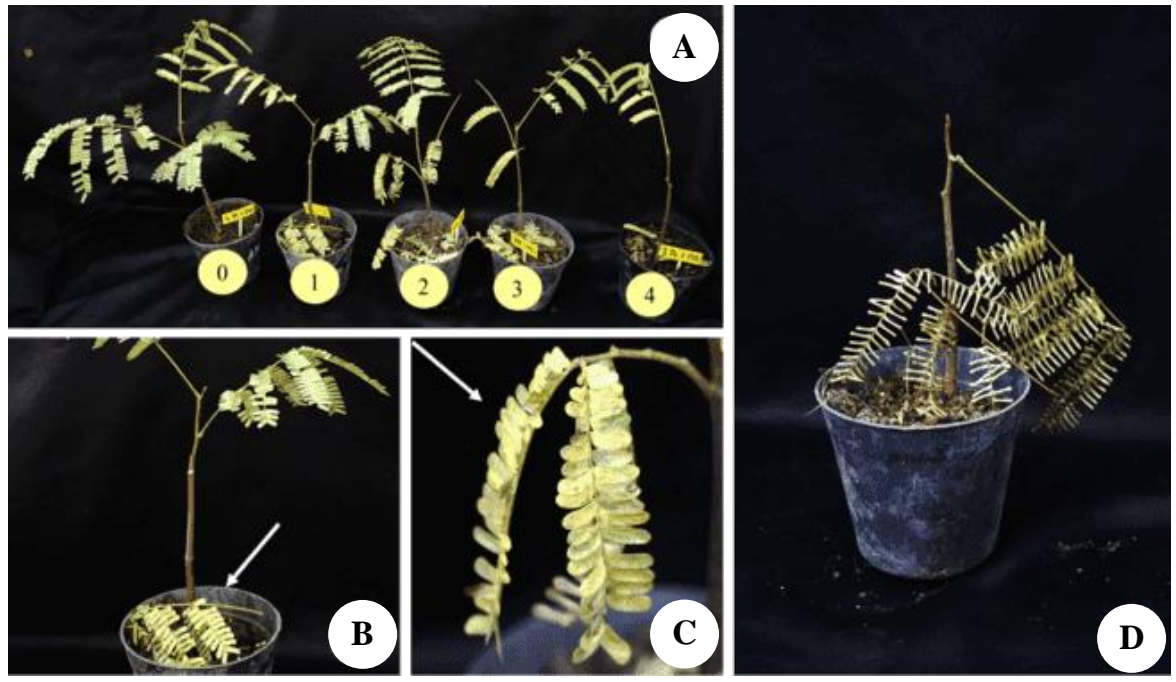

Figure 6. Disease index on Parkia speciosa. A. From left: healthy plant to $100 \%$ wilted leaves (score 0-4); B. Initial symptoms: yellowing and dry from oldest leaves; C. Advanced symptoms: curved leaves; yellowing, D. Dead plant

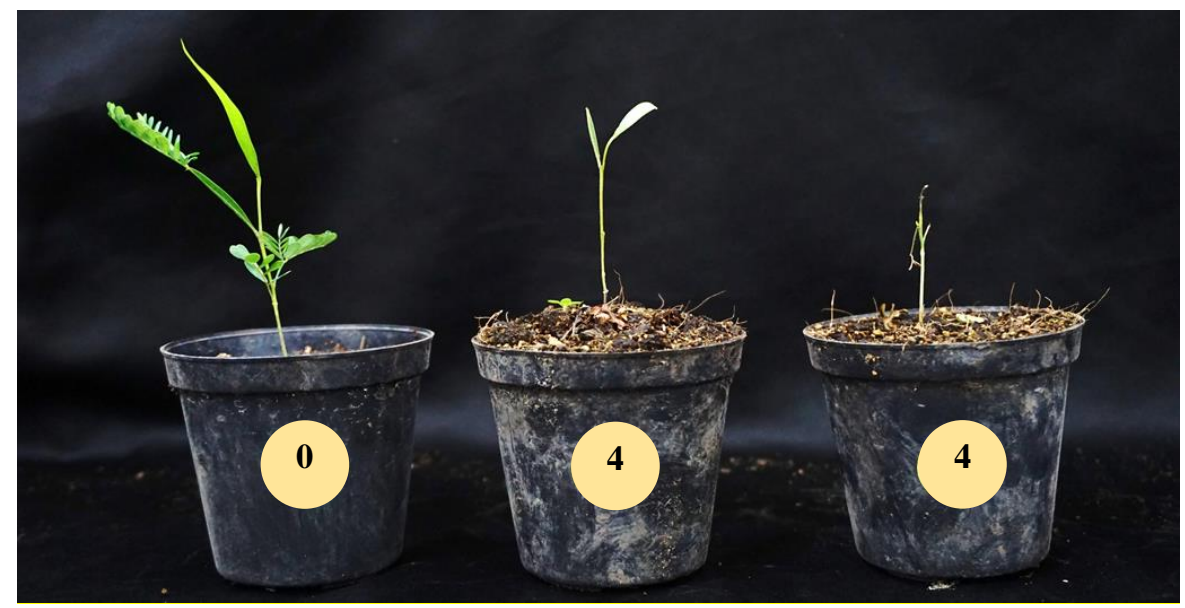

Figure 7. Disease index on Acacia auriculiformis, from left: healthy plant to wilted and dead plant (score 0-4) 


\section{RESULTS AND DISCUSSION}

\section{Pathogenicity test}

The results showed that all the six forest plants tested had a similar reaction to the pathogen. Seven days after inoculation, all the plants showed typical symptoms of $F$. oxysporum infection, i.e. yellowing of oldest leaves closest to the stem base, which gradually progresses to younger shoots, severe wilting, drying, falling of leaves, and eventually plant die. Another symptom that appeared was sudden wilting and death of plant without changing the leaf color, while control plants did not show any symptoms (Figures 2-7).

Disease severity was significantly higher than controls. $A$. crassicarpa and $F$. moluccana were most severely affected with an average score of 4.00 and 3.44, respectively. On the other hand, A. pauciflorum, $L$. leucocephala, and $P$. speciosa were showed moderate disease severity, i.e. 1.96, 1.68, and 1.80, respectively, whereas A. auriculiformis had the lowest (0.36) disease severity (Table 1). Based on the disease score, host plants were classified into three groups: (i) highly susceptible ( $A$. crassicarpa and $F$. moluccana), (ii) moderately susceptible (A. pauciflorum P. speciosa, and L. leucocephala), and (iii) moderate resistance/tolerance (A. auriculiformis). Results exhibited that there was no significant difference between the disease severity in the same host that had been inoculated with different isolates (Table 1).

\section{Fusarium oxysporum population}

The total population of $F$. oxysporum on the roots was determined by calculating the CFU for each category of damage. For DI 4, A. crassicarpa and F. moluccana showed a significantly higher population $(82.00-105.10 \times$ $10^{4} \mathrm{CFU} \mathrm{g}^{-1}$ fresh weight) than other plants. The lowest population was recorded in $P$. speciosa and $A$. pauciflorum (3.57-12.27 $\times 10^{4} \mathrm{CFU} \mathrm{g}^{-1}$ fresh weight). This same pattern also occurred in DI 2 and 3, while no sample was recorded in A. auriculiformis for DI 2 and 3. In DI 1, the highest population was recorded in $F$. moluccana and $L$. leucocephala, while A. crassicarpa and A. auriculiformis had no sample for DI 1 . In inoculated plants with DI 0 , the population was significantly higher in L. leucocephala and A. auriculiformis and no sample was noted in $A$. crassicarpa and $F$. moluccana (Table 2 and Table 3 ).

The regression analysis results showed that all plants except $P$. speciosa had a linear relationship pattern between the increase in disease score and population. The pathogenic population on $A$. crassicarpa and $F$. moluccana grew rapidly along with the increase in disease scores, as indicated by the magnitude of regression gradient coefficient $(\mathrm{m}=20.3-21.3)$. However, moderate increase was observed in L. leucocephala $(\mathrm{m}=11.2)(\mathrm{m}=11.2)$ and very slow in $A$. pauciflorum, $P$. speciose, and $A$. auriculiformis $(\mathrm{m}=2.2-4.8)$ (Figure 8$)$.

Table 3 showed that isolates were different in tefl- $\alpha$, but the population and DI patterns were similar for each test plant. The correlation between the population of pathogen $\left(\mathrm{g}^{-1}\right.$ fresh weight) and the level of DI was described as follows: i) high pathogen populations with high DI (A. crassicarpa and $F$. moluccana), ii) moderate population with moderate DI (L. leucocephala), iii) low population with moderate DI (A. pauciflorum), and iv) low population with low DI (P. speciosa and A. auriculiformis).
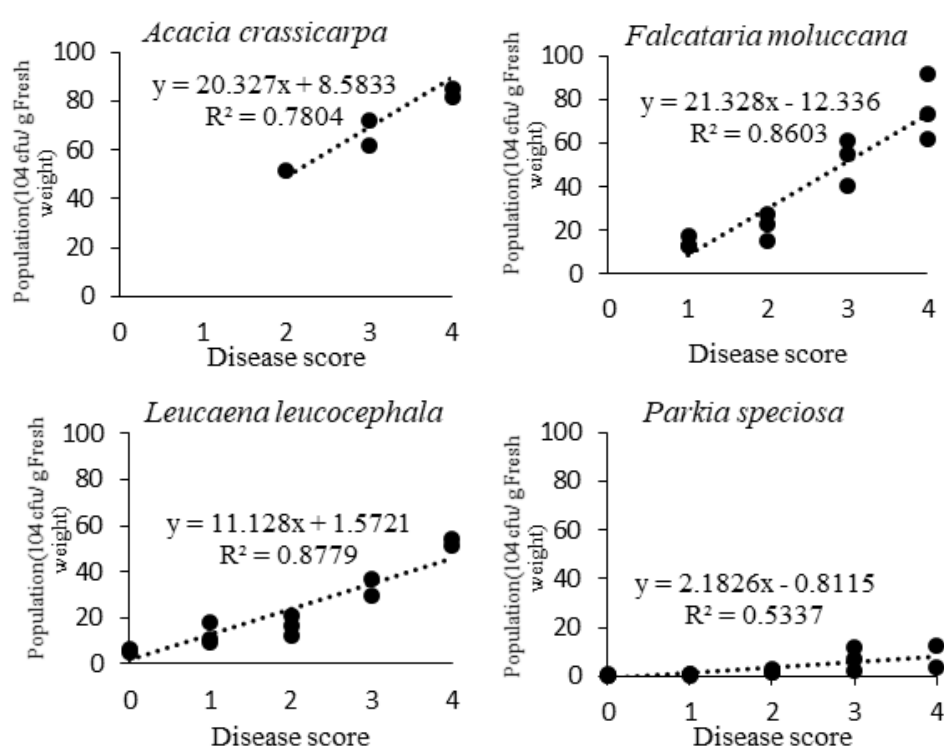
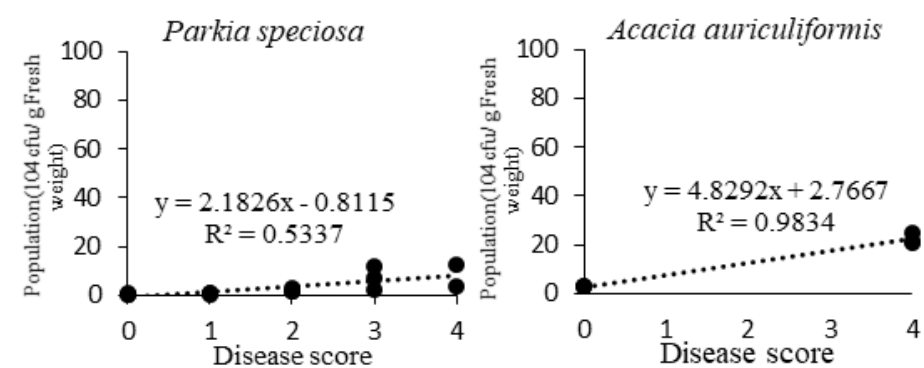

Figure 8. Regression analysis of disease score rate and Fusarium oxysporum population 
Table 1. Disease severity and host responses to Fusarium oxysporum isolated from Acacia mangium

\begin{tabular}{|c|c|c|c|c|c|c|}
\hline \multirow{2}{*}{ Plant species } & \multicolumn{6}{|c|}{ Isolates a) } \\
\hline & AF01 b) & Response $^{\mathrm{c})}$ & BF05 & Response & DF11 & Response \\
\hline Acacia crassicarpa & $4.00 \mathrm{a}$ & $\mathrm{HS}^{\mathrm{c})}$ & $3.48 \mathrm{a}$ & HS & $3.96 \mathrm{a}$ & HS \\
\hline Falcataria moluccana & $3.44 \mathrm{ab}$ & HS & $3.04 \mathrm{a}$ & HS & $2.80 \mathrm{ab}$ & $\mathrm{S}$ \\
\hline Archidendron pauciflorum & $1.96 \mathrm{bc}$ & MS & $1.88 \mathrm{~b}$ & MS & $1.40 \mathrm{~cd}$ & MS \\
\hline Leucaena leucocephala & $1.52 \mathrm{c}$ & MS & $1.56 \mathrm{~b}$ & MS & $1.68 \mathrm{bc}$ & MS \\
\hline Parkia speciosa & $1.80 \mathrm{c}$ & MS & $1.04 \mathrm{bc}$ & MS & $2.16 \mathrm{bc}$ & S \\
\hline Acacia auriculiformis & $0.36 \mathrm{~d}$ & MR & $0.40 \mathrm{c}$ & MR & $0.60 \mathrm{~d}$ & MR \\
\hline
\end{tabular}

Note: Values followed by the same letter in each row are not significant. ${ }^{a}$ DI $0-4$, where 0: no disease/healthy seedling, 1: yellow leaves, 2: yellow leaves and slightly wilted, 3: severe wilt, and 4: dead seedling. ${ }^{\text {b) }} \mathrm{F}$. oxysporum isolates. ${ }^{\text {c) }}$ Host response grouped as: R: resistant $(\mathrm{DI}=0)$; MR: moderately resistant/tolerance $(\mathrm{DI}=<1)$; MS: moderately susceptible $(\mathrm{DI}=1.0-2.0)$; S: susceptible $(\mathrm{DI}=$ 2.1-3.0); HS: highly susceptible (DI = 3.1-4.0) (Bertetti et al. 2018).

Table 2. Fusarium oxysporum population on root in each disease index

\begin{tabular}{|c|c|c|c|c|c|c|}
\hline \multirow{2}{*}{ Plant species } & \multicolumn{5}{|c|}{ Population of Fusarium oxysporum $\left(\times 10^{4} \text { CFU/g fresh weight }\right)^{\text {a) }}$} & \multirow{2}{*}{ Average $^{\mathrm{c})}$} \\
\hline & $\mathbf{0}^{\mathrm{b})}$ & 1 & 2 & 3 & 4 & \\
\hline \multicolumn{7}{|l|}{ AF01 d) } \\
\hline Acacia crassicarpa & n.s & n.s & n.s & n.s & $85.13 \mathrm{a}^{\mathrm{e})}$ & 85.13 \\
\hline Falcataria moluccana & n.s & $17.77 \mathrm{a}$ & $22.77 \mathrm{a}$ & $60.98 \mathrm{a}$ & $91.87 \mathrm{a}$ & 76.50 \\
\hline Archidendron pauciflorum & $0.45 \mathrm{~b}$ & $1.10 \mathrm{~b}$ & $3.22 \mathrm{~b}$ & $8.15 \mathrm{~b}$ & $12.53 \mathrm{~cd}$ & 5.06 \\
\hline Leucaena leucocephala & $6.17 \mathrm{a}$ & $18.10 \mathrm{a}$ & $20.93 \mathrm{a}$ & n.s & $51.67 \mathrm{~b}$ & 22.13 \\
\hline Parkia speciosa & $0.32 \mathrm{~b}$ & $0.45 \mathrm{~b}$ & $2.58 \mathrm{~b}$ & $7.27 \mathrm{~b}$ & $3.57 \mathrm{~d}$ & 2.16 \\
\hline Acacia auriculiformis & $2.92 \mathrm{a}$ & n.s & n.s & n.s & $24.53 \mathrm{c}$ & 4.65 \\
\hline \multicolumn{7}{|l|}{ BF05 } \\
\hline Acacia crassicarpa & n.s & n.s & $51.80 \mathrm{a}$ & $72.08 \mathrm{a}$ & $105.10 \mathrm{a}$ & 92.61 \\
\hline Falcataria moluccana & n.s & $13.22 \mathrm{a}$ & $15.32 \mathrm{~b}$ & $40.33 \mathrm{~b}$ & $61.67 \mathrm{~b}$ & 43.85 \\
\hline Archidendron pauciflorum & $0.47 \mathrm{c}$ & $0.63 \mathrm{~b}$ & $1.73 \mathrm{c}$ & $6.88 \mathrm{c}$ & $9.90 \mathrm{~d}$ & 3.60 \\
\hline Leucaena leucocephala & $4.67 \mathrm{a}$ & $9.02 \mathrm{a}$ & $12.32 \mathrm{~b}$ & $29.32 \mathrm{~b}$ & n.s & 11.16 \\
\hline Parkia speciosa & $0.48 \mathrm{c}$ & $0.57 \mathrm{~b}$ & $1.27 \mathrm{c}$ & $2.33 \mathrm{~d}$ & n.s & 0.87 \\
\hline Acacia auriculiformis & $2.55 \mathrm{~b}$ & n.s & n.s & n.s & $20.43 \mathrm{c}$ & 3.98 \\
\hline \multicolumn{7}{|l|}{ DF11 } \\
\hline Acacia crassicarpa & n.s & n.s & n.s & $61.92 \mathrm{a}$ & $82.00 \mathrm{a}$ & 81.20 \\
\hline Falcataria moluccana & n.s & $12.50 \mathrm{a}$ & $27.47 \mathrm{a}$ & $54.93 \mathrm{a}$ & $73.00 \mathrm{a}$ & 47.93 \\
\hline Archidendron pauciflorum & $0.35 \mathrm{c}$ & $0.35 \mathrm{~b}$ & $3.37 \mathrm{c}$ & $4.42 \mathrm{c}$ & $6.92 \mathrm{e}$ & 2.19 \\
\hline Leucaena leucocephala & $5.58 \mathrm{a}$ & $11.17 \mathrm{a}$ & $16.53 \mathrm{~b}$ & $36.63 \mathrm{~b}$ & $54.27 \mathrm{~b}$ & 19.69 \\
\hline Parkia speciosa & $0.25 \mathrm{c}$ & $0.48 \mathrm{~b}$ & $1.58 \mathrm{c}$ & $11.97 \mathrm{~d}$ & $12.27 \mathrm{~d}$ & 5.79 \\
\hline Acacia auriculiformis & $2.83 \mathrm{~b}$ & n.s & n.s & n.s & $21.28 \mathrm{c}$ & 5.05 \\
\hline
\end{tabular}

Note: n.s: No sample, cfu: colony-forming unit. ${ }^{\text {a) }}$ F. oxysporum population calculated at the end of the experiment (21 days after inoculation). b) DI 0-4; 0: no disease/healthy seedling; 1: yellow leaves; 2: yellow leaves and slightly wilted; 3: severe wilt; and 4: dead seedling. ${ }^{\text {c) }}$ Average of $F$. oxysporum population (cfu/g fresh weight $)=\left(\mathrm{P}_{0} \mathrm{~A}+\mathrm{P}_{1} \mathrm{~B}+\mathrm{P}_{2} \mathrm{C}+\mathrm{P}_{3} \mathrm{D}+\mathrm{P} 4 \mathrm{E}\right) / \mathrm{N}$; where $\mathrm{P} 0, \mathrm{P} 1, \mathrm{P} 2, \mathrm{P} 3$, and $\mathrm{P} 4$ : population of pathogen in score $0,1,2,3$, and 4 : A: number of plants on score 0 ; B: number of plants on score 1; C: number of plants on

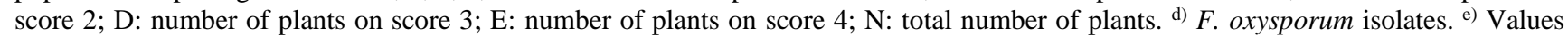
followed by the same letter in each row are not significant.

Table 3. Fusarium oxysporum population average and diseases index of plant

\begin{tabular}{|c|c|c|c|c|c|c|}
\hline \multirow{2}{*}{ Plant species } & \multicolumn{3}{|c|}{ Population average $\left(\times 10^{4} \mathrm{CFU} / \mathrm{g} \text { fresh weight }\right)^{\text {a) }}$} & \multicolumn{3}{|c|}{ Disease index ${ }^{b)}$} \\
\hline & $\mathrm{AFO1}^{\mathrm{c})}$ & BF05 & DF11 & AF01 & BF05 & DF11 \\
\hline Acacia crassicarpa & 85.13 & 92.61 & 81.20 & 4.00 & 3.48 & 3.96 \\
\hline Falcataria moluccana & 76.50 & 43.85 & 47.93 & 3.44 & 3.04 & 2.80 \\
\hline Archidendron pauciflorum & 5.06 & 3.60 & 2.19 & 1.96 & 1.88 & 1.40 \\
\hline Leucaena leucocephala & 22.13 & 11.16 & 19.69 & 1.52 & 1.56 & 1.68 \\
\hline Parkia speciosa & 2.16 & 0.87 & 5.79 & 1.80 & 1.04 & 2.16 \\
\hline Acacia auriculiformis & 4.65 & 3.98 & 5.05 & 0.36 & 0.40 & 0.60 \\
\hline
\end{tabular}

Note: a) Average of $F$. oxysporum population (cfu/g fresh weight): $\left(\mathrm{P}_{0} \mathrm{~A}+\mathrm{P}_{1} \mathrm{~B}+\mathrm{P}_{2} \mathrm{C}+\mathrm{P}_{3} \mathrm{D}+\mathrm{P}_{4} \mathrm{E}\right) / \mathrm{N}$; where $\mathrm{P} 0, \mathrm{P} 1, \mathrm{P} 2, \mathrm{P} 3$, and $\mathrm{P} 4$ : population of pathogen in score $0,1,2,3$, and 4 : A: number of plants on score 0 ; B: number of plants on score 1; C: number of plants on score 2; D: number of plants on score 3; E: number of plants on score; N: total number of plants. b) DI 0-4; 0: no disease/healthy seedling; 1: yellow leaves; 2 : yellow leaves and slightly wilted; 3: severe wilt; and 4: dead seedling. ${ }^{\text {c) }} F$. oxysporum isolates 


\section{Discussion}

A recent study reported an extraordinary incidence of seedling wilt disease caused by fungal pathogen $F$. oxysporum attacking commercial nurseries of A. mangium in South Sumatra (Soleha et al. 2021). Therefore, the investigation of a new host of the pathogen is an important step in the plant protection strategy for soil-borne diseases. Host range tests also provide information about plant species that have the potential to become alternative hosts or main hosts for the pathogen (Sampaio et al. 2021).

The results indicated that $F$. oxysporum, which causes vascular wilt in A. mangium nursery, can also infect Fabaceae plants with various host responses. $A$. crassicarpa and $F$. moluccana were highly susceptible, while A. pauciflorum, L. leucocephala, and P. speciosa were moderately vulnerable, and A. auriculiformis was moderately resistant. Pathogen caused wilting symptoms in all test plant species with DI of 4.00. Although DI was lower (0.36) in A. auriculiformis, but it had the potential to damage plants. Fusarium oxysporum is able to infect plants even with a low DI, causing the death of cultivars. Moreover, when a plant is grown in contaminated soil, there is a high risk of damage to crops. A similar incident was reported by Pastrana et al. (2017) in which $F$. oxysporum from blackberry also caused sudden death in strawberries. Another study also revealed that $F$. oxysporum from cactus causes root and stem rot diseases in Euphorbia (Bertetti et al. 2017).

The results revealed that several types of plants belonging to the Fabaceae family had great potential to become an alternative host and even main host for $F$. oxysporum when planted in the same field. Widespread of this pathogen may allow interaction with new plants (EdelHermann and Lecomte 2019; Sampaio et al. 2021). Moreover, the planting of new species affected the occurrence of new outbreaks because the pathogenic strains adapted to the soil and had become virulent (Sampaio et al. 2021; Stukenbrock and McDonald 2008). Furthermore, nursery activities that use contaminated soil repeatedly also triggered the proliferation and adaptation of the pathogens to other plants.

The pathogen population in A. crassicarpa and $F$. moluccana grew very rapidly with increasing disease scores, while in L. leucocephala grew moderately, and $A$. pauciflorum, $P$. speciose, and $A$. auriculiformis grew slowly. In this study, the population of $F$. oxysporum on highly susceptible plants (A. crassicarpa and $F$. moluccana) was significantly higher than other plants for each disease score. This pattern is common where the population of pathogen is also higher with disease scores (Scott et al. 2014). de Borba et al. (2017) reported that susceptible lettuce cultivars showed high Fusarium population level and vulnerable black bean genotype showed a population level of $15.4 \times 10^{5} \mathrm{CFU}^{\mathrm{g}-1}$. The second pattern was observed on L. leucocephala, where the population of pathogen was also moderate with a moderate diseases score. A similar result was also occurred in garlic with disease severity of $44 \%$ due to Fusarium spp. infection, which showed a moderate number of pathogens on roots (Molinero-Ruiz et al. 2011).
A special pattern occurred on A. pauciflorum in which $F$. oxysporum caused a moderate infection, but the pathogen population was low. This might be due to the plant defense mechanism. Scott et al. (2014) reported that resistant pepper plants also support pathogen development in roots, even without external symptoms. Similar phenomenon was reported by Muslim et al. (2003a) who noted that some tomato plants are infected moderately (score 1-2) by $F$. oxysporum f. sp. lycopersici, but the population was lower than other plants in same score.

The infection and total population on Parkia speciosa and A. auriculiformis were lower. This indicated that plants belonged to the resistant plant group. Fang et al. (2012) reported that when resistant strawberry plants were inoculated with $F$. oxysporum f. sp. fragariae, the cultivar formed a barrier with accumulated phenolic cells in the hypodermal layer that effectively limits the pathogen colonization and prevent the invasion of root vascular tissue. If the tissue penetration by hyphae was limited to the epidermis, then the pathogens do not reach the vascular tissue. Van Den Berg et al. (2007) reported that banana clones tolerant to $F$. oxysporum $\mathrm{f}$. sp. cubense correspond with this, with a significant increase in the induction of cell wall-associated phenolic compounds. Jiménez-Fernández et al. (2013) also reported that Fusarium oxysporum f. sp. ciceris race 0 remained in the intercellular space of root cortex and failed to reach xylem in resistant chickpea cultivars.

In this study, A. crassicarpa and $F$. moluccana were proven to be an alternative host of $F$. oxysporum. Whereas L. leucocephala, A. pauciflorum, $P$. speciosa, and $A$. auriculiformis had potential as alternative hosts. Many plants of Fabaceae family were attacked by formae specialis $F$. oxysporum, such as Vigna angularis ( $F$. oxysporum f. sp. adzukicola), Cicer arietinum, Cicer spp. (F. oxysporum f. sp. ciceris), Acacia spp. (F. oxysporum f. sp. koae), Lens culinaris, L. esculenta ( $F$. oxysporum f. sp. lentis), Medicago sativa ( $F$. oxysporum f. sp. medicaginis), Phaseolus vulgaris, $P$. coccineus (F. oxysporum f. sp. phaseoli), Pisum sativum, Cicer arietinum ( $F$. oxysporum $\mathrm{f}$. sp. pisi) (Edel-Hermann and Lecomte 2019). However, in this study, $F$. oxysporum isolated from $A$. mangium has a wide host range from Fabaceae family; therefore, it is not classified as formae specialis.

In conclusion, $F$. oxysporum isolated from A. mangium causes infection in several types of forest and industrial plants. Since it has a wide host range, it is not classified as part of the formae specialis group.

\section{ACKNOWLEDGEMENTS}

This research was funded by the Directorate General of Research and Development, Ministry of Research, Technology and Higher Education, Indonesia through the PMDSU scholarship 2020-2021 according to the Director of Research and Community Service, Ahmad Muslim, with the number 0124/UN9/ SB3.LP2M.PT/2020. 


\section{REFERENCES}

Asif MJ, Govender NT, Ang LH, Ratnam W. 2017. Growth performance and lignin content of Acacia mangium Willd. and Acacia auriculiformis A. Cunn. ex Benth. under normal and stressed conditions. J For Sci 63: 381-392. DOI: 10.17221/100/2015-JFS.

Bertetti D, Ortu G, Gullino ML, Garibaldi A. 2017. Identification of Fusarium oxysporum f. sp. opuntiarum on new hosts of the Cactaceae and Euphorbiaceae families. J Plant Pathol 99: 347-354. DOI: 10.4454/jpp.v99i2.3874.

Bertetti D, Gullino ML, Garibaldi A. 2018. Susceptibility of some Papaveraceae plants to Fusarium oxysporum f. sp. papaveris. J Plant Dis Prot 125: 103-108. DOI: 10.1007/s41348-017-0095-7.

Borges RCF, Macedo MA, Cabral CS, Rossato M, Fontes MG, Santos MDM, Ferreira MA, Fonsea MEN, Reis A, Boiteux LS. 2018 Vascular wilt of teak (Tectona grandis) caused by Fusarium oxysporum in Brazil. Phytopathol Mediterr 57: 115-121. DOI: 10.14601/Phytopathol.

Burkhardt A, Henry PM, Koike ST, Gordon TR, Martin F. 2019 Detection of Fusarium oxysporum f. sp. fragariae from infected strawberry plants. Plant Dis 103: 1006-1013. DOI: 10.1094/PDIS-0818-1315-RE.

de Borba MC, Garcés-Fiallos FR, Stadnik MJ. 2017. Reactions of black bean seedlings and adult plants to infection by Fusarium oxysporum $\mathrm{f}$ sp. phaseoli. J Crop Prot 96: 221-227. DOI 10.1016/j.cropro.2017.02.019.

Edel-Hermann V, Lecomte C. 2019. Current status of Fusarium oxysporum formae speciales and races. Phytopathology 109: 512-530. DOI: 10.1094/PHYTO-08-18-0320-RVW.

Fang X, Kuo J, You MP, Finnegan PM, Barbetti MJ. 2012. Comparative root colonisation of strawberry cultivars Camarosa and Festival by Fusarium oxysporum f. sp. fragariae. Plant Soil 358: 75-89. DOI: 10.1007/s11104-012-1205-8.

Horinouchi H, Watanabe H, Taguchi Y, Muslim A, Hyakumachi M. 2011. Biological control of Fusarium wilt of tomato with Fusarium equiset GF191 in both rock wool and soil systems. Biocontrol 56 (6): 915923. DOI: 10.1007/s10526-011-9369-3.

Ignjatov M, Milosevic D, Nikolic Z, Gvozdanovic-Varga J, Jovicic D, Zdjelar G. 2012. Fusarium oxysporum as a causal agent of tomato wilt and fruit rot. Pestic Phytomed 27: 25-31. DOI: 10.2298/pif1201025i.

Jacobs A, Van Heerden SW. 2012. First report of Fusarium oxysporum $\mathrm{f}$. sp. radicis-lycopersici in South Africa. Australas Plant Dis Notes 7 29-32. DOI: 10.1007/s13314-011-0039-1.

Jiménez-Fernández D, Landa BB, Kang S, Jiménez-Díaz RM, NavasCortés JA. 2013. Quantitative and microscopic assessment of compatible and incompatible interactions between chickpea cultivars and Fusarium oxysporum f. sp. ciceris Races. PLoS ONE 8: 0061360 DOI: 10.1371 /journal.pone.0061360

Joshi R. 2018. A review of Fusarium oxysporum on its plant interaction and industrial use. J Med Plants Stud 6: 112-115. DOI: 10.22271/plants.2018.v6.i3b.07.

Koutika L, Richardson DM. 2019. Acacia mangium Willd: benefits and threats associated with its increasing use around the world. For Ecosyst 6: 1-13. DOI: 10.1186/s40663-019-0159-1.

Koyyappurath S, Atuahiva T, Le Guen R, Batina H, Le Squin S, Gautheron N, Edel Hermann V, Peribe J, Jahiel M, Steinberg C, Liew ECY, Alabouvette C, Besse P, Dron M, Sache I, Laval V, Grisoni M 2016. Fusarium oxysporum $\mathrm{f}$. sp. radicis-vanillae is the causal agent of root and stem rot of vanilla. Plant Pathol 65: 612-625. DOI: 10.1111/ppa.12445.

Leslie JF, Summerell BA. 2006. The Fusarium Laboratory Manual. Blackwell Publishing, Oxford. DOI: 10.1002/9780470278376.

Li XG, Liu B, Heia S, Liu DD, Han ZM, Zhou KX, Cui JJ, Luo JY, Zheng YP. 2009. The effect of root exudates from two transgenic insectresistant cotton lines on the growth of Fusarium oxysporum. Transgenic Res 18 (5): 757-767. DOI: 10.1007/s11248-009-9264-1.
Luo X, Yu C. 2020. First report of damping-off disease caused by Fusarium oxysporum in Pinus massoniana in China. J Plant Dis Prot 127: 401-409. DOI: 10.1007/s41348-020-00303-3.

Matsumura, Naoto. 2011. Yield Prediction for Acacia mangium Plantations in Southeast Asia. Formath 10: 295-308. DOI: 10.15684/formath.10.295.

Molinero-Ruiz L, Rubio-Pérez E, González-Domínguez E, BasalloteUreba MJ. 2011. Alternative hosts for Fusarium spp. causing crown and root rot of Asparagus in Spain. J Phytopathol 159: 114-116. DOI: 10.1111/j.1439-0434.2010.01723.x.

Muslim A, Horinouchi H, Hyakumachi M. 2003a. Biological control of Fusarium wilt of tomato with hypovirulent binucleate Rhizoctonia in greenhouse conditions. Mycoscience 44: 77-84. DOI: 10.1007/s10267-002-0084-x.

Muslim A, Horinouchi H, Hyakumachi M. 2003b. Control of Fusarium crown and root rot of tomato with hypovirulent binucleate Rhizoctonia in soil and rock wool systems. Plant Dis 87: 739-747. DOI: 10.1094/PDIS.2003.87.6.739.

Muslim A, Hyakumachi M, Kageyama K, Suwandi, Pratama R. 2019. A rapid bioassay to evaluate efficacy of hypovirulent binucleate Rhizoctonia in reducing Fusarium crown and root rot of tomato. Open Agric J 13: 27-33. DOI: 10.2174/1874331501913010027.

Pastrana AM, Kirkpatrick SC, Kong M, Broome JC, Gordon TR. 2017. Fusarium oxysporum f. sp. mori, a new forma specialis causing fusarium wilt of blackberry. Plant Dis 101: 2066-2072. DOI: 10.1094/PDIS-03-17-0428-RE.

Rana A, Sahgal M, Johri BN. 2017. Fusarium oxysporum: Genomics, diversity and plant-host interaction. Dev Fungal Biol Appl Mycol. Springer, Singapore. DOI: 10.1007/978-981-10-4768-8_10.

Rooney-Latham S, Blomquist CL. 2011. First report of Fusarium wilt caused by Fusarium oxysporum $\mathrm{f}$. sp. passiflorae on passion fruit in North America. Plant Dis 95: 1478. DOI: 10.1094/PDIS-03-11-0261.

Sampaio AM, Rubiales D, Vaz Patto MC. 2021. Grass pea and pea phylogenetic relatedness reflected at Fusarium oxysporum host range. J Crop Prot 141: 1-8. DOI: 10.1016/j.cropro.2020.105495.

Scott JC, Mcroberts DN, Gordon TR. 2014. Colonization of lettuce cultivars and rotation crops by Fusarium oxysporum f. sp. lactucae, the cause of fusarium wilt of lettuce. J Plant Pathol 63: 548-553. DOI: 10.1111/ppa.12135

Soleha S, Muslim A, Suwandi S, Kadir S, Pratama R. 2021. The identification and pathogenicity of Fusarium oxysporum causing acacia seedling wilt disease. J For Res. DOI: 10.1007/s11676-02101355-3.

Stewart JE, Abdo Z, Dumroese RK, Klopfenstein NB, Kim M. 2011. Virulence of Fusarium oxysporum and Fusarium commune to Douglas-fir (Pseudotsuga menziesii) seedlings. For Pathol 42 (3): 220-228. DOI: 10.1111/j.1439-0329.2011.00746.x.

Stukenbrock EH, McDonald BA. 2008. The origins of plant pathogens in agro-ecosystems. Annu Rev Phytopathol 46: 75-100. DOI: 10.1146/annurev.phyto.010708.154114.

Taylor A, Armitage AD, Handy C, Jackson AC, Hulin MT, Harrison RJ, Clarkson JP. 2019. Basal rot of Narcissus: Understanding pathogenicity in Fusarium oxysporum f. sp. narcissi. Front Microbiol 10: 1-17. DOI: 10.3389/fmicb.2019.02905.

Van Den Berg N, Berger DK, Hein I, Birch PRJ, Wingfield MJ, Viljoen A. 2007. Tolerance in banana to Fusarium wilt is associated with early up-regulation of cell wall-strengthening genes in the roots. Mol Plant Pathol 8: 333-341. DOI: 10.1111/j.1364-3703.2007.00389.x.

Widyastuti SM, Tasik S, Harjono. 2013. The infection process of Fusarium oxysporum fungus: A cause of damping-off on Acacia mangium seedlings. Agrivita 35: 110-118. DOI: 10.17503/Agrivita2013-35-2-p110-118.

Zhang L, Song J, Shen J, Tan G, Li S, Ding F. 2013. First report of stem canker on phoenix trees (Firmiana simplex) caused by Fusarium oxysporum in China. J Phytopathol 161: 128-130. DOI: 10.1111/jph.12033. 